\title{
Etik Modanın Temsiliyeti Bağlamında Vaatleri ve Çelişkileri: ‘Etik Moda’ Ne Kadar Etik Sunuluyor?
}

\author{
Şölen KIPÖZ *, Duygu ATALAY **
}

Özet

Hızlı modanın üretim ve tüketim stratejilerinin yarattığı yıkıcı etkilerin görünür hale gelmesi, modanın yeniden tanımlanmasını sağlayan etik ve ekolojik bir tasarım anlayışının benimsenmesine yol açmıştır. Böylece etik moda 'Yavaş Moda Akımı' gibi yaratıcı söylemler geliştirmiş ve yerel zanaatları, adil ticareti, çok işlevli tasarım ürünlerini, katılımcı tasarımı, çevre dostu malzemelerin kullanımını ve geri dönüşümle değer kazandırılan tasarımları yücelten bir yapıya kavuşmuştur. Ancak küresel moda ekonomisi tarafından ticarileştirilerek asimile de olmuştur. Etik moda, başat sistem içerisinde tüketilebilen bir trende dönüştürülürken, sanal ortamda varlık gösteren niş bir medya ile beslenen alternatif bir tasarım hareketi olarak sınırlı kalmıştır. Bu makalede, etik modanın tasarım ve üretim stratejileri bağlamında söylemsel ve ticari temsiliyeti ele alınarak ana akım ve alternatif medyada yer alan haberlerin geriye dönük okuması yapıımıştır. Böylece etik modanın vaat ettiği 'etik olma’ sözü, medya analizi üzerinden deşifre edilmiştir.

Anahtar Sözcükler: Etik Moda, Etik Moda Söylemi, Modanın Temsiliyeti, Moda Basını, İnternet Dergiciliği.

\section{Promises and Conflicts of Ethical Fashion within the Context of its Representation: How Ethically is 'Ethical Fashion' Presented?}

\section{Abstract}

Realization of devastating effects of fast fashion production and consumption strategies led embracement of an ethical and ecological design understanding that ensures redefinition of fashion. Thus, ethical fashion developed creative discourses such as 'Slow Fashion Movement' and gained a structure that praises local crafts, fair trade, multifunctional design products, participatory design, use of environmentally friendly materials and upcycled designs. However, it has also been assimilated via commercialization by the global fashion economy. While ethical fashion is transformed into a trend which can be consumed within the frame of dominant fashion system, it remained limited as an alternative design movement that is supported by the niche media which is transmitted through digital domain. Within this paper, in regards to design and production strategies of ethical fashion, discursive and commercial representations of it are analyzed by backcasting the literal and visual representations of ethical fashion in conventional and alternative media. Thereby the promise of 'being ethical' that ethical fashion propounds is dechipered through the media analysis.

Keywords: Ethical Fashion, Ethical Fashion Discourse, Representation of Fashion, Fashion Media, Online Magazine Publishing 


\section{Giriş}

Etik tasarım anlayışının gündeme gelmesi tasarımın hangi koşullarda yaratıldığı, üretildiği ve tüketildiğinin sorgulanmasıyla ilgilidir. Bir tasarımın etik olup olmadığı, kurumsallaşmış bir tasarım sistemi ve endüstrisinin sorumluluğunda değerlendirilecek bir yargıdır. Bu yapıdaki temel aktörleri tasarımcı, üretici ve tüketici olarak ele alırsak, aktörler arasındaki ilişkinin lineer ve hiyerarşik olduğunu, tasarımcı ile üreticinin, tüketici üzerinde manipulatif bir rol oynadığını gözlemleyebiliriz. Bu çerçevede, tasarımda etik kavramını tartışan tasarım kuramcısı Clive Dilnot'un (2009: 180) benzetmesiyle; tasarımcı pazar ekonomisine hizmet eden bir hizmetkar, tüketici ise bir ürünü ya da hizmeti kullanan insan değil, müşteri olarak konumlandırılır. Bourdieu'ya göre modanın bir kültürel sermaye haline gelebilmesi için bu yapıya iletişim-medya aktörü de eklenir ve bu tepeden inme ilişkide ana akım moda medyası, tasarımcıyı ve üretimini bir ekonomik değer olarak var edebilmek adına tüketim odakı bir anlatı kurar.

Küresel modanın 'yapmaya' ve 'ilerlemeye' yönelik üretim-tüketim arasındaki bu lineer ve hiyerarşik ilişki, tasarım kuramcısı Manzini'nin (1995: 235, 236) tarif ettiği şekliyle "üretmek için yapmaya" dayanan ve "atık" oluşturan bir süreçtir. Oysa, bu ilişkiyi döngüsel bir yapıda kurgulayıp ‘yeniden üreterek' sonuç ürünün birçok geri kazanım oluşturabileceğini görebiliriz. Böyle bir sürecin iletişim ayağı da, tüketim odaklı ve manipüle edici bir söylemden ziyade şeffaf, bilgilendirici ve tüketiciyi okuyup yorumlayan bir birey olarak konumlandıran katılımcı bir yapılanmayı benimseyecektir. Son on yıllık süreçte etkisi meşrulaşan etik moda anlayışı, kendi moda iletişimini ve söylemini ana akım moda basını üzerinden etkin bir biçimde oluşturamamakta ve kendine özgü iletişim kanallarına ihtiyaç duymaktadır. Modanın üretimini sağlayan ana akım medya, etik moda haberlerine yer vermektedir. Etik moda üzerinden niş bir ticari alan yaratıp 'yeşil tüketim' olgusunu yaratmaktadır. Oysa ekolojik, sürdürülebilir, yavaş ve sosyal yaklaşımları ilke edinen etik moda, iletişim yöntemi olarak şeffaf, katılımcı ve eleştirel bir söylemi benimser. Bu çerçevede oluşturdu- ğu nadir kaynakların çoğunluğunu çevrimiçi, interaktif ve sosyal medya iletişim araçları oluşturur.

$\mathrm{Bu}$ çalışmanın amacl, moda endüstrisinin yarattığı çevresel kirliliğe, tüketime yönelik üretim anlayışına, iş gücü sömürüsüne, adil olmayan ticarete karşı geliştirilen uygulamaların tümünü kapsayan etik moda hareketini, iletişim biçimi ve temsiliyeti üzerinden okumaktır. Her ne kadar, etik moda, küresel moda sisteminin içerisinde kurumsal bir yer edinmek yerine tabandan yayılan bir aktivist dönüşüm olarak varlık gösterse de kendine özgü iletişim kanalları üzerinden kendi söylemini inşa etme çabası içerisindedir. Öte yandan, artık lüks olmaktan çıkıp gereklilik haline gelen sürdürülebilirlik ve ekoloji kavramları moda literatüründe yer edindiğinden, etik moda uygulamaları modanın konvansiyonel iletişim kanalları tarafından asimile edilme durumuyla yüz yüzedir. Bu çerçevede çalışma şu sorulara cevap aramaktadır; Kendine özgü iletişim kanalları aracılı̆̆ı ile söylemini oluşturabilen ve başat moda medyası içerisinde az da olsa bir rolü olan etik modanın ileti ve okunma biçimleri arasında ne gibi farklılıklar vardır? Genellikle internet dergiciliği üzerinden yayın yapan, eleştirel ve tarafsız yapısı ile bir niş iletişim aracı olarak var olan etik moda medyasının günümüz moda endüstrisinde durduğu yer nedir? Etik modanın, başat moda sistemindeki meşruiyeti çerçevesinde, başat moda medyasındaki temsiliyeti ne denli doğru, tarafsız ve eleştirel, dolayısı ile ne denli etiktir? Bu sorular ışı̆̆ında, etik modanın gelişimi, değer ve ölçütleri, moda medyası ve söylemi açısından tasarım-üretim-tüketim ilişkisi incelemiştir. Ana akım moda medyası ile etik moda medyasının karşılaştırılması etik moda içerikleri bağlamında yapılmıştır.

\section{Araştırma yöntemi}

Tasarım literatüründe son otuz yılın gündemini dolduran etik ve sürdürülebilir tasarım, moda tasarımında yaklaşık on yıldır etkin bir söylem oluşturmaktadır. 2006 yılında 'yavaş tasarım hareketi manifestosunun' (Clark, 2008) moda dünyasında yarattığı yankı ile birçok etik marka internet üzerinden küresel ölçekte iletişim kurmaya başla- 
mıştır. 90'lı yıllarda kavramsal tasarım hareketinin öncülerinden Martin Margiela'nın 'atık' olarak nitelendirilen eski giysilere kazandırdığı yeni statü (Evans, 1998: 81, Kipöz, 2013), etik modanın ana akım medyada ilgi çekici konulardan biri haline gelmesine yol açmıştır. Margiela ve çağdaşlarının öncülük ettiği kavramsal ve radikal moda tasarımı, güncel modanın yalnızca gösterilen, alınıp, satılan bir değer değil, aynı zamanda üzerinde konuşulan, tartışılan ve sergilenen kalıcı bir değer olduğunu vurgulayarak bu alanda akademik bir literatürün de oluşumunu sağlamıştır. Buna paralel olarak başat moda sistemine eleştirel yaklaşan etik ve ekolojik moda literatürü de disiplinler arası akademik dünyada kendini göstermeye başlamıştır.

Etik modanın benimsediği iletişim kanallarına ve söylemlerine odaklanan bu araştırma kapsamında, söylemlerin analiz edilebilmesi için gereken "etik modanın oluşumu”, "değerleri” ve "ana akım moda medyasının işleyişi” konularının aktarımı kitap ve makaleler üzerinden yapılırken, etik moda söyleminin güncel tezahürü çevrimiçi kaynaklardan oluşan dergi okuma ve analizlerinden oluşmaktadır. Bu okumada son beş yılda (20082013) medyanın etik ve sürdürülebilir modaya nasıl yer verdiği ele alınarak, etik modanın tasarım değerleri bağlamında ana akım moda medyası ve etik moda medyası arasındaki benzerlikler/farklar bulgulanmıştır. Söylemsel/eleştirel ve betimsel/promosyonel okuma biçimleri arasındaki farklar, etik moda markalarının özellikleri ve dergilerin üslupları bağlamında tartışılmıştır. İlaveten, istatistiki veri elde etme çabası güdülmeksizin, tasarım değerleri bağlamında paradigma olarak ele alınan markaların dergilerdeki haberlerinin dağılımı sayısal olarak da verilmiştir.

\section{Tasarım Hareketi olarak Etik Modanın Oluşumu}

Etik moda, yalnızca sürdürülebilirlikle kısıtlı olmak yerine, sosyal, kültürel ve ekonomik dönüşümlerle aktivist bir hareket olarak gelişmektedir. Baskın moda sistemi veya siyasi iktidarlar tarafından empoze edilen dikey bir oluşum olmaktan ziyade, tabandan yayılan sosyal bir dönü- şüm olarak değerlendirilmelidir. Bu dönüşümü tetikleyen kırılma noktalarını hatırlamak önem taşımaktadır:

- ‘Ekolojik Hümanizm': Sürdürülebilir tasarım 1960’lı ve 1970'li yıllarda gündeme gelen 'çevresel duyarlılığın' ve "sürdürülebilir tüketimin" ortaya çıkışına tekabül eder (Jackson, 2002'den aktaran Thorpe, 2010: 2). 68 kuşağının sosyal ve politik huzursuzluğu ile yeşeren Hippie devrimi, kapitalist düzenin homojenleştirici değerlerine karşı sembolik bir dil oluştururken, 'Kendin-Yap' ve 'Geri-Dönüştür' pratiğinin ilk örnekleriyle küresel moda sisteminin dikey hiyerarşisine bir başkaldırı niteliğindedir.

-Dayanışma kültürü ve Gençlik Hareketleri: Punklar da burjuva kapitalizmini sorgulayarak 'KendinYap' kültürünün en yaratıcı düzeyini göstermişlerdir. Punk'ların tüketim toplumuna karşı dirençleri eleştirel ve agresiftir. Pazar ekonomisinde talep gören yepyeni, cazibeli ürünlere karşı, paçavra ve çöp kültürünün değersizliğine prim vermişlerdir. Robyn Healy (2007: 665) Punkların pasif tüketim değerlerine nasıl direnç gösterdiklerini şöyle ifade etmektedir; "Yeni giysilerin ve görünümün statüsünün yarattığı fetişist arzuya karşı, Punklar düzensiz, kullanılmış, yırtılmış, çamura batmış, değersiz objeler ve modası geçmiş aksesuarlarla dekore edilmiş giysileriyle statü karşıtı bir stil benimsemişlerdir.

- ‘Sürdürülebilir Tüketim': 1980’lerin tüketim toplumunu takip eden süreçte, ekolojik humanizmden sonra ikinci dalga, Rio'da 1992'de Çevre ve Gelişim üzerine Birleşmiş Milletler tarafından düzenlenen 'Earth Summit' zirvesi ile gerçekleşmiştir. Zirvedeki oturumların raporu olarak yayınlanan Agenda 21'le sürdürülebilir ve küresel ölçekte sorumlu bir dünya düzeni için yapılması gerekenlerin kaydı oluşturulmuştur (Margolin, 2002: 101). Earth Summit, sürdürülebilirlik kültürünün oluşumuna ışık tutarken, etik tüketim uluslararası politikalar bağlamında tanınan bir olguya dönüşmüştür (Jackson, 2002'den aktaran Thorpe, 2010: 4; Margolin, 2002: 96).

- 'Yeşil Tüketim': Ekolojik bilinç zamanla kendisini moda pazarında da göstermiş ve yeşil tasarımlar ticarileşmeye başlamıştır. Sandy Black (2008: 22-23) hazır giyim 
devi Espirit firmasının 1990'lı yıllarda pazara sunduğu 'Ecollection' adlı ekolojik koleksiyonu ile bu akımın öncülüğünü yaptığını kaydeder. Ekolojik kadın koleksiyonları üretmek için oluşturulan ekibin hedefleri, tasarımcı Lynda Grose tarafından şöyle ifade edilmiştir; "Klasik tasarım ve dayanıkı üretim ile ürün ömrünü uzatmak; insan yapımı liflerin kullanımını en aza indirmek veya tamamıyla ortadan kaldırmak; toprakta çözünebilir veya geri dönüştürülmüş malzemelerin kullanımıyla atık sahalarındaki yoğunluğu önlemek; sürdürülebilir tarım ve çiftçiliği teşvik etmek; kendilerinin etik ve çevresel amaçlarını paylaşan firmalarla çalışmak ve moda endüstrisini etkilemek".

- 'Ekolojik Tasarım': Sürdürülebilir ve sorumlu bir gelecek için tasarımın rolü niceliğin yerine niteliğin konulması açısından önem kazanmaktadır. Manzini'nin (1995, 226), önerdiği gibi “nicelik temasının önemi niteliğin yeni rolü ile sarsılmış”, tasarımcılar sektörde egolarını tatmin etmekten çok sosyal roller benimsemeye başlamışlardır. Thorpe'a (2010: 4) göre tasarım, sürdürülebilir tüketimin özendirilmesi bağlamında yaşam biçimlerinin değişiminde belirleyici bir rol üstlenmiştir. Yazar, tasarımcıdaki bilinç değişiminin tüketim kalıplarına yansımasına yönelik verimli tüketim yerine (örneğin altı yerine iki t-shirt almak) giysilerin yıkanmasının eko-sistemde bıraktığı etkilerden hareketle bir tasarım önerisinin 'yıkanmayan gömlek' olabileceği örneğini vermiştir. Böylece tasarımcı, otomatikleşmiş davranış kalıplarını eleştirerek tüketiciler üzerinde sorumluluk bilinci yaratabilmektedir.

- 'Yapısökümcü Tasarım Hareketi': Derrida'nın yapısöküm felsefesi, modanın yenilik tutkusu ile beslenen 'kullan-at' kültürüne gösterilen bir direnç olarak çağdaş moda tasarımında yapısal bir dönüşümün tohumlarını atmıştır (Kipöz ve Güner, 2011). Hareketin öncülüğünü yapan tasarımcılardan, "dekonstrüksiyon yöntemini bir program niteliğinde uygulayan" Martin Margiela (Loschek, 2009: 187), zanaata ağırlık verdiği Artisanal koleksiyonuyla tasarımda 'geri dönüşüm' ve 'yeniden kullanım' ilkelerini kavramsal bir anlayışla yorumlamıştır. Tasarımlarında ikinci el asker giysileri gibi moda hiyerarşisinde en düşük değişim değerine sahip malzemeler kullanmıştır.
'Değersiz' parçalara yeni yaşamlar ve moda hiyerarşisinde yüksek statü ve prestij kazandırmış (Evans, 1998: 83), böylece modanın yarattığı değerler sisteminin de yapısökümünü gerçekleştirmiştir.

- “Etik Tasarım Söylemi”: Margolin (2002), tasarımcıların insani sorunlara dokunan ve sosyal rahatlı̆ga katkıda bulunan maddi ve manevi ürünleri hayata geçirme yetenekleri olduğunu vurgular. Ekolojik tasarıma yönelik bu eleştirel ve diyalektik bakış açısı etik moda söyleminin de oluşumunu tetiklemiştir. Başat moda medyasına alternatif olarak gelişen etik moda medyasının varlığını göstermesi de bu oluşumun bir parçasıdır. 1970'lerden itibaren popüler moda dergilerindeki etik tüketimi özendiren moda haberleri 1990'larda yoğunlaşmıştır. Ancak başat basılı medyanın ticari ve tüketimi özendiren yaklaşımı içerisinde kendi söylemini oluşturamayan etik moda, iletişim kanalı olarak web üzerinden işleyen blogları seçmiştir. Bu kanallar aracılığı ile oluşan etik moda medyası söylemine ileride kapsamlı olarak yer verilmektedir.

- 'Yavaş Moda Hareketi': Söylemini Milano'da bir konferansta gündeme gelen 'Yavaş Tasarım Manifestosu' ışığında oluşturmuş ve etik moda söyleminin yaratıcı zeminini inşa etmiştir. "Yavaş moda, modayı etik harekete dönüştürebilecek en temel konulardan birine işaret eder; tüketimin kendisinin başlı başına bir sorun olduğuna" der Arnold (2009: 102). Fletcher’a (2008) göre, yavaş moda; tasarım, üretim ve tüketim arasında kurulan denge içerisinde "kalite" nin üretimi, değer kazanması ve işlenmesi ile ilişkilidir. Hazel Clark (2008: 429) Yavaş Moda Manifestosu'nun üç ana amacını şöyle özetler;

1. Yerel iş gücü, yerel malzemeler ve zanaatla hızlı moda sisteminin neden olduğu tek-tipleştirici, anti demokratik uygulamalar ve eşitsizlik, kirlenme gibi problemleri çözmek.

2. Üretici ve tüketici arasında daha az aracının olduğu şeffaf üretim sistemleri kurarak kapitalizm ve seri üretim yöntemlerinin sebep olduğu işçinin ürüne, tüketicinin üretime yabancılaşı̆ı̆ı hiyerarşik yapıyı kırmak. 
3. Tipik eşyadan daha değerli kılınan sürdürülebilir, uzun ömürlü, geri dönüştürülebilen ve duyusal ürün tasarımları yaparak tüketim kültürüne direnç gösterme yöntemleri geliştirmek.

\section{Moda Medyasının Söylemine Direnç Gösteren Etik Moda Söylemi}

Etik modanın varlığı başat sisteme direnç göstermesinden kaynaklanır ve bunu yaparken sistemin dışında kalmak yerine sistemin içinden, modanın yöntem, dil ve kabul görmüş değerlerini yapı-sökümüne uğratmaya çalışır. Küresel moda sisteminin tasarım-üretim-tüketim ilişkisini olduğu kadar, iletişim ve temsiliyet biçimini de sorgular. Bu diyalektik ilişkinin tabiatını anlamak için moda sisteminin söylem üretme sürecinin ve moda medyasının sürece olan katkılarının anlaşılması gerekir. Bu sürecin okunmasında Bourdieu'ya referans vererek bir kültür endüstrisi olan modanın şeyler üretmekten çok, şeylerin sembolik değerini üretmekten ibaret olduğunu hatırlamamız gerekir (Rocamora, 2009: 54-57) . Bu görüş, Baudrillard'ın (1981) post-endüstriyel dönemde şeylerin kullanım değerinden değişim değerine geçiş yaptığı ve son aşamada 'işaret değeri' statüsüne yükseldiği saptaması ile uyuşmaktadır. Modanın sembolik üretimini görünür kılan işaret değeri, moda söylemini var eden olgunun ürün değil, ürünün imgesi ve temsiliyeti olduğunu da doğrular. Nitekim Sontag da Debord'un 'Cösteri Toplumu'na referans vererek 'çă̆ımız şeyin yerine imge, orijinali yerine kopya, gerçekliğin yerine temsiliyeti ve varoluşun yerine görüntüsünü tercih eder' derken benzer bir okuma yapmıştır (Evans, 1972: 153'den aktaran Shinkle, 2008: 25).

Moda gösterileri ve basınıyla ortaya çıkan bu temsiliyet, gerçeğin aktarımından çok 'yüceltilmiş bir söylem' (celebratory discourse) üretir. Bourdeiu'ya göre sembolik üretimde uzmanlaşmış, spesifik bir alanın paydaşlarına yönelik üretilen, kolektif bir nitelik taşıyan bu söylem aynı anda tanımlama (describe) ve yönlendirme (prescribe) özelliğini paylaşır (aktaran Rocamora, 2009: 5457). Başka bir ifade ile Evans'ın (aktaran Shinkle, 2008: 19) hiyerarşik ve protokollerden oluşan hermetik bir yapı olarak tanımladığı moda sistemi Rocamora'nın deyimi ile "kendisini kutsamak için monopolik bir güç" oluşturan bir söylem yaratır. Yazar, bir moda kenti, moda söylemi ve moda medya söylemi arasındaki ilişkileri Bourdieu ve Foucault'un görüşleri açısından değerlendirir. Foucault için söylem bilgiyi üreten anlatımların düzenidir. Bourdieu, moda söyleminin belirli bir zamanda, üretildiği ve yeniden üretildiği belirli bir yerde baskın olan esaslar bütünü olduğuna işaret ederken, Foucault bu esasların tüm toplumlarda güçlerini ve risklerini savuşturmakla yükümlü yordamlar tarafından denetlendiği, seçildiği, düzenlendiği, dolayısıyla söylemsel üretimin daha geniş bir sosyal bağlamı olduğunu savunur (aktaran Rocamora, 2009: 5560).

Moda medyası, dergilerden, gazetelere, raporlara ve reklamlara kadar farklı format ve biçimlerde görünürlüğe sahip olan ve bu kanallar aracılığı ile söylem oluşturan modanın ayrıcalıklı alanlarıdır. Basın söyleminin böylesine kapsayıcı olması başat modanın gücünü ve etkisini artırdığı gibi etik modanın da kendine özgü kanallarla söylem üretme potansiyelini güçlendirir. Bu noktada bu söylemlerin benzerliği ve ayrılığını belirleyebilmek için başat moda medyasının dergiler aracılığı ile içeriğini ve dilini nasıl inşa ettiğine bakmak gerekir.

\section{Moda Basını ve Dergiciliğinin Yapısı}

Moda sisteminin oluşumu, sistemin inşasında başlıca rolü oynayan medya sistemiyle eş zamanlı ve eş karakterlidir. Moda ve moda medyası söylemleri karşıııkı olarak birbirlerini tekrar tekrar üretirler. 18. yüzyılda gerçekleşen Sanayi Devrimi'yle reprodüksiyon ve basım tekniklerindeki ilerlemeler sayesinde uzmanlaşmış moda dergilerinin alt yapısını oluşturan, kadının toplumsal rolünü, cinsel kimliğini ve moda davranışlarını inşa eden kadın dergileri ilk olarak İngiltere'de yaygınlaşmıştır (Wolbers, 2009; Craik, 1993). Ataerkil yapının ürünü olan kadın dergileri, öncelikle kadının ev ekonomisine katkı sağlayan, annelik ve kadınlık görevini yapan ve kendisiyle birlikte evini de güzelleştiren domestik rolünü öne çıkarmışlardır. Pazar ekonomisinin gelişimiyle 'tüketici kadın' profili oluş- 
muş ve dergilerin içeriğindeki reklamların sayısı artmıştır (Craik, 1993: 48-49). Bu dönüşümü ve modanın tüketiciye yönelik temsiliyetini Craik (2009: 248) şöyle tanımlar: "modanın kadın tüketiciye sergilenmesi ve çekici hale getirilmesi, içerisinde reklamcıların, vitrin düzenleyicilerin, mankenlerin ve moda yazarlarının bulunduğu bir tüketim endüstrisine hayat vermiştir. Böylece "modanın temsiliyeti’ kendi başına bir metaya dönüşmüştür”. Dergiler, okuyucuyu potansiyel bir moda tüketicisi olarak tanımlarken, tüketicilerin tahayyüllerinde 'modanın temsilcisi' olma hayalini inşa etmek için belli 'moda görünümleri’ ve idealize edilen belli davranış kalıplarını empoze ederler.

Dergilerin yazı işleri müdürü derginin içeriğine karar veren kişi olarak moda hiyerarşisinde tasarımcıdan sonra ikinci sırada kabul edilir. Aslında derginin temsil ettiği ve yer verdikleri moda dünyası açısından o kadar yönlendiricidir ki bu hiyerarşi bazen tersine döner. Wolbers (2009: 172) "dergi için yer altın değerindedir" derken yer verilenler ve verilmeyenler arasındaki farkın altını çizmektedir. Kawamura'nın da belirttiği gibi (2005) dergi editörlerinin iki önemli silahı; "yer ve sessizliktir". Editörler belirli bir konu hakkında sessiz kalma hakkını kullanabilir ya da bu konuyu yücelterek öne çıkarabilirler. Reklam verenler için yer para demektir ve dergiler gelirlerini okuyucu tirajlarından çok reklam gelirlerinden elde ettiklerinden firmaların kazançlarının sürekliliğ̈ini sağlamayı görev edinirler. Okuyuculara o markaların birer tüketicisiymiş gibi seslenir ve daha çok o firmaların haberlerini paylaşırlar (Currie, 1994). Bunun dışında firmaların/tasarımcıların dergide bir köşe kapabilmek için editörleri defilelere, partilere, açılışlara davet ederek, hatta hediyeler göndererek memnun etmeye çalıştıklarına sıklıkla rastlanır (Craik, 2009).

"Moda dergiciliğindeki habercilikte en önemli eleştiri unsuru, dergilerin eleştiriye yer vermemeleridir." diyen Wolbers (2009: 177), moda dergilerinin diğer aktüel süreli yayınlardan en önemli farkının reklam verenlere bağlılıkları olduğunu vurgular. Metinlerin yazım dilinin eleştirel olmaktan çok olumlayıcı olduğunu da ifade eden yazar, "dergide negatif yorumlara yer yoktur" ifadesini kullanır. Benzer biçimde Wilson (1982'den aktaran Bre- ward, 1995: 197) da "çoğu moda tarihçisince iddia edildiği gibi dergilerin, sosyal ve stilistik değişimin barometreleri olarak algılanmalarının" gerçeği yansıtmadığını savunur. Bu yargı, söylem analizinde ifade edildiği gibi, 19. yüzyıldan bu yana üründen çok imajın ve temsiliyetin önem kazanması ile dergilerin tanımlar gibi görünürken yönlendirmeleri ve tüketimi teşvik etmeleri ile açıklanabilir. $\mathrm{Bu}$ nedenle moda dergilerinin dilleri reklamcllık diliyle benzerlik göstermektedir. Wilson, (1982'den aktaran Breward, 1995: 197) bu durumu şu sözlerle özetler: "Kadın dergilerinin dili didaktik yani eğitici bir anlatım biçiminden tıpkı reklamcılıkta olduğu gibi halüsinatif bir dile geçmiştir. Popüler gazeteciliğin ve reklamcılı̆̆ın asıl amacı bilgi vermekken bugünkü durumu itibariyle illüzyona dayanan bir varoluş biçimini empoze eder niteliktedir. Karşılaştığımız durum basitçe bir taklit etme sürecini değil, bilinçsizce özdeşleşme halini yansıtır”.

Bu görüşler ışığında basılı medyanın, başat modanın pratiklerini ve söylemlerini sorgulayan ve tüketimi riske eden bir dili benimsemekten kaçındığı sonucu çıkarılabilir. Bu nedenle etik moda kendi söylemini alternatif bir medya içeriği üzerinden gerçekleştirmek durumundadır. Ayrıca etik moda medya söylemi yer imgesi üzerinden hareket eden basılı basından çok, dolaşıma sahip olan internet ortamında etkin olabilmektedir. Zira 'yavaş moda' sözcüğüne ilk kez internetteki makaleler ve bloglarda rastlanmıştır (Martin, 2005; Sayer, 2007'den aktaran Clark, 2008: 428). "Yavaş Giysi Hareketi” kavramı ise ilk kez Georgia Straight isimli Vancouver kökenli bir internet dergisinde yazar olan Angela Murrills tarafından 2004 yıIında tanımlanmıştır (Richmond, 2006'dan aktaran Clark, 2008: 428). Ayrıca, internet, etik giysi tasarımlarının pazarlanmasına da ciddi katkı sağlamıştır (Scaturro, 2008).

Yavaş Moda Manifestosunun etkisiyle Armani, Stella McCartney gibi ünlü tasarımcılar organik koleksiyonlarının tanıtımını yaptıktan sonra konvansiyonel moda dergileri konuya ilgi göstermeye başlamışlardır. 2006 yıında Vanity Fair dergisi 'Yeşil' konulu ek fasikülü çıkarınca derginin editörü yeşil meta fetişizminin müjdesini vermek için ‘Yeşil Yeni Siyahtır’ sloganını yaratmıştır (Winge, 
2008: 511). 2008 yilında Vogue, sonra Elle dergisi her yıl yeşil ek fasikül yayınlamaya başlamışlardır. Bu gösteriyor ki, geleneksel basın içerik oluşumunda ticari yapısını riske edeceğini düşündüğü etik konulara yer vermeyip, etik moda oluşumu karşısında sessiz kalmayı tercih ederken, konu diğer basın organlarında gündeme gelerek popülerleştiğinde yayın içeriğine almakta veya derginin içeriğine müdahale etmeden yeşil eklerle sözde duyarlılığını göstermektedir. Bu durum Wilson'un ileri sürdüğü moda dergilerinin sosyal değişimleri yansıtma konusundaki pasifliğine işaret eetmektedir. Bunun yerine dergiler güncel konuları ticarileştirme eğilimindedirler (Breward, 1995).

Dergiler ticarileştirme sürecini bazı stilleri tüketiciye empoze ederek yürütürler ve Baudrillard'ın (1972) ‘yanıtsız iletişim' olarak nitelendirdiği tek taraflı bir iletimi başlatırlar. Bu terimle moda dergilerinin mesajların tek yönlü yani, derginin her zaman mesaj veren ve okuyucunun mesaj alan konumda olduğu bir sistem yarattıkları vurgulanmaktadır. Böylelikle; dergiler, moda sisteminin işleyişinde 'iletişimsizliğin' kaynakları olurlar. Etkileşimsiz bir ortamda kendilerini iletici bir konumda pozisyonlandırırken, modanın insan ve doğa üzerindeki yıkıcı etkileri konusunda sessiz kalarak sistemin tek yanlı görünümünü sunarlar.

Basılı ortamın tekelci yaklaşıma karşın, internet alternatif bir platform oluşturur. 1990'larda World Wide Web kurumsal medya devlerinin merkezileşmiş gücüne karşın etkin bir kaynak oluşturduğunda, internet demokratik iletişimi sağlayabilecek bir umut olarak görülmüştür (Herman ve Swiss, 2000: 4). Bilginin yalnızca seçili bir azınlık tarafından değil, internet erişimi olan herkesçe üretilebilir ve erişilebilir bir hale dönüştürülmesi basılı medyaya hakim olan 'yanıtsız iletişime' meydan okumaktadır. Illaveten, bilginin ve iletişimin yayılımı sanal ortamda hızlı olduğundan tek tarafı ıir mesajın uzun süre geçerli olmayacağı gerçeği ortaya çıkmaktadır.

Internet, etik modayı benimseyen tasarımcılar ve söylemini üretenler için demokratik bir ortam yaratır. Clark (2008: 434) Yavaş+Tasarım Manifestosu'na refe- rans vererek internetin "maddi kaynak akışı yerel kalırken, tasarım ve bilginin küresel bir alanda seyahat ettiği bir yapı" olarak kullanıldığını vurgular. Ayrıca internet tüketicinin hem alıcı hem de satıcı olduğu yeni tüketim biçimleri üreten bir ortamdır. Clark, bu modelin ürün ve servislerin üreticiden tüketiciye aracısız olarak aktığı, satış bilgisi olarak üretim süreçlerinin, malzemelerin, insani ve çevresel koşullarının aktarıldığı bir platform yarattığının da altını çizmiş̧tir (Clark, 2008: 435). Böylece bu yapı şeffaf bir bilgi akışı oluşturduğu gibi, endüstrinin dağıtım sistemindeki birçok fiziksel birimi de ortadan kaldırarak, hem bu birimlerin ve servislerin maliyetlerinden elde edilen kazanımı tüketiciye yansıyan ekonomik bir işe çevirir, hem de bu fiziki yapıların çevreye verdiği zararları elimine eder.

\section{Etik Moda Söylemini Yaratan Değerler}

Çalışma kapsamında kullanılan 'etik moda' terimi, "yoğun kaynak tüketimiyle kirlilik yaratan moda endüstrisinin" (Fletcher, 2008: 5) tüm eylemlerinin sürdürülebilir, ekolojik ve sosyal tasarım çerçevesinde şekillendirilmesine işaret eder. Bu kavram yalnızca malzeme odaklı fiziksel bir dönüşümden ziyade bütünsel bir yaklaşım olarak ele alınmalıdır. Etik moda sistemin tamamının ustaca planlanmasına işaret eder ve kendi söylemini bir dizi değerler üzerinden oluşturur. Söylemin belkemiğini oluşturan değerler aynı zamanda makale kapsamında mercek altına alınan ana akım ve etik medya sistemlerinin dil ve içeriğini birbirinden ayıran kriterleri de oluşturmaktadır. Araştırma kapsamında, etik modanın medyadaki temsiliyeti bu değerler doğrultusunda analiz edilmektedir:

\section{Çevre-dostu Malzemelerin Kullanımı}

1960'ların “Ekolojik Hümanizm” hareketinden bu yana, malzemeler sürdürebilirliğin merkezinde yer almışlardır. 1990'ların doğal ve geri dönüştürebilen lifleri sürdürülebilir giyim üretimini olanaklı kılmıştır (Fletcher, 2008). 2000'lerde ise organik ve dürüst ticaret mamulü yeni ekolojik lifler ortaya çıkmıştır. Etik modanın çevreci sloganlar ve işlem görmemiş t-shirt tasarımları ile sınırlandırılan moda-dışı çizgisi, ekolojik tekstillerde 
gerçekleşen yenilikçi yaklaşımlarla daha yaratıcı ve estetik bir kimlik kazanmış ve pek çok giyim üreticisinin doğal, organik, su ve enerji sarfiyatını azaltan malzemeler kullanmasını özendirmiştir.

\section{Yeniden Değerlendirme/Yeniden Kullanım/Geri Dönüştürme ve Değer Kazandırma}

Kitlesel tüketim ve moda trendlerindeki hızlı değişimler Fletcher'in (2008) da işaret ettiği gibi esas itibari ile demode olarak kabul edilen pek çok giysinin 'atık' olarak değerlendirilmesine yol açmaktadır. Doğrusal bir yapıya sahip olan başat moda sisteminin işleyişi dört aşamada gerçekleşir; tasarım-üretim-tüketim-elden çıkarma. Bu süreçte elden çıkarma bir giysinin yaşam döngüsünün son aşamasıdır. Yeniden Değerlendirme/ Yeniden Kullanım/ Geri Dönüştürme ve Değer Kazandırma yaklaşımı son aşamayı ilk aşama olarak yeniden değerlendirerek bu doğrusal işleyişi döngüsel bir yapıya dönüştürmeyi amaçlar. Daha az giysiüretimini ve tüketimini özendirirken, eski giysileri onarma ve onlara yeni bir hayat kazandırmaya dayanır. Böylece, 'atık', yeni giysiler yaratmak için kaynak oluşturur ve "bir değer ve güzellik unsuru olma konumuna yükselir” (Fletcher, 2008: 98). Bu tasarım yöntemi genel olarak "tasarımla değer kazandırma" (upcyling) olarak nitelendirilebilir (McDonough ve Braungart, 2002).

\section{Kendin-Yap ve Katılımcı Tasarım}

Seri üretim yaygınlaşana dek birçok ürün kullanıcısı tarafından tasarlanıp üretilmiştir. Endüstriyel ilerlemeler sonucu zamanla terk edilen bu tür uygulamalar, savaş ve ekonomik buhran dönemleri dişında 1970'li ve 1980'li yıllarda varlık gösteren alt kültürler tarafından benimsenmiştir. Kendin-yap pratiği bugün de egemen sistemin dikte ettiği tasarım, üretim ve tüketim kalıplarına bir başkaldırıdır. Bu pratik, 1970'li yıllarda İskandinavya'da işyeri tasarımını demokratikleştirmek ve sendikaların "çalışan üyelerini etkileyecek sistemlerin oluşumunda aktif rol almasını sağlamak" (Erlhoff ve Marshall, 2008: 210) amacıyla yapılan uygulamalarla ortaya çıkan katılımcı tasarım kavramıyla da paraleldir. Katılımcı tasarım, tüketiciyi tasarım ve üretim süreçleri içine dâhil etmeyi amaçlar. Bu yaklaşım bir ürünün tüketim, yani değişim değerinden çok yaşam deneyiminden 'değer' oluşturmayı benimser. Böylece tüketicinin 'alıcı' pasif rolünü, 'yaratıcı' aktif bir kimliğe dönüştürmeyi hedefler ve tüketicinin "yalnızca pratik ve fiziksel düzeyde giysilerin kesimi yada dikimine müdahale ettiği değil, aynı zamanda, sürece politik, ekolojik ve ekonomik olarak katıldı̆̆ı" bir sistemi öngörür (Fletcher, 2008: 194).

\section{Yerel Malzemelerin Kullanımı, Yerel İşgücü ve Yerel Zanaat}

Küresel tasarımcılar, gelişmekte olan toplumların kültürel ve otantik zanaat becerilerini değerlendirmek yerine, bu kültürlerin etnografik değerlerini küresel pazarın beklentilerine uygun biçimde kopyalamışlardır. Zanaat becerisine yönelik malzemeler ise Orta doğu, Afrika ve Hindistan gibi bölgelerden ithal edilmiş, ama bu bölgelerin üretici toplulukları merkezdeki tasarım ve üretim süreçlerinden dışlanmışlardır. Sürdürülebilir ve etik modanın gündeme gelmesi ile pek çok tasarımcı bu topluluklarla işbirliğine girerek ortak bir üretme zemini yaratmaya başlamıştır. Uluslararası markalarla ortaklık kuran üretici toplulukların "düşük maliyetli işçiliği ve geleneksel zanaat becerileri sömürülmek yerine onurlandırılmıştır" (Brown, 2010: 13). Böylece Batı ülkelerinin tekelinde homojenleşmiş küresel moda sistemi yerel sistemlerin kurduğu bir ağ olarak yeniden yapılanmıştır (Clark, 2008: 430).

\section{Etik Moda'nın Sanal Medya Üzerinden Geriye Dönük Okunması}

Çalışmanın bu bölümünde etik modanın sanal ortamda nasıl temsil edildiği, yorumlandığı ve desteklendiği incelenmiştir. Ana akım moda medyası ile etik moda medyasının karşılaştırılması iki aşamada yapılmıştır. İlk aşamada yalnızca haber yapma ve makale yayınlama sıklıklarına bakılmıştır. İkinci aşamada ise sanal ortamda yayınlanan haber ve makalelerin içeriklerinin analizi yapılmıştır. Konvansiyonel moda dergilerinin web siteleri olan 'Vogue.com', ‘Elle.com' ve 2008 yılından bu yana sadece sanal ortamda var olan kendilerini etik moda sitesi 
olarak tanımlayan 'Ecouterre' in içerikleri analiz edilmiştir. 2008-2013 (2013 yılının Temmuz ayına kadar) yılları arasında yapılan geriye bakış analizi, web sitelerinde etik moda prensiplerine hangi ölçüde yer verdiklerini ortaya koyma amacı taşımaktadır.

Aşağıdaki tablolarda, dergilerin web sitelerinde yayınlanan etik moda ile ilgili makale sayıları verilmiştir. Bu veri oluşturulurken etik modanın söylemini oluşturan değerlerden üretilen anahtar sözcükler sitelerin arama bölümlerine yazılarak haberlere ulaşılmıştır. Bu anahtar sözcükler 'Organik', 'Yeşil Moda', 'Ekolojik Moda', 'Yavaş Moda', 'Değer kazandırma', 'Geri dönüştürme', 'KatıımCl Tasarım', 'Adil Ticaret' ve 'Yerel' olarak belirlenmiştir. Araştırma, kadın giyimine yönelik haberler ve makalelerle sınırlandırılmış, aksesuar, mücevher, takı, gelinlik, mayo gibi haberler araştırma dışında bırakılmıştır. İncelenen makalelerin içeriğinde belirlenen anahtar kelimelerin geçmesine veya ima edilmesine dikkat edilmiştir. Örneğin haber içerisinde organik pamuk, organik keten ve doğal boyalar kullandığı belirtilen bir tasarımcı ekolojik malzemeler kategorisinde değerlendirilmiş̧ir. Kimi makaleler veya haberlerde bahsi geçen tasarımcı veya markalar birden fazla kategoriye girebilmektedir. Örneğin bazı firmalar hem ekolojik malzemeler kullanmakta, hem geri dönüştürmekte hem de yerel üretim yapmaktadır. Böyle firmaların haberleri makale içinde vurgusu daha çok yapılan kategori kapsamında değerlendirilmiştir.

\begin{tabular}{|c|c|c|c|c|}
\hline Vogue & $\begin{array}{l}\text { Cevie Dostu } \\
\text { Malsemelerta } \\
\text { Kullinuman }\end{array}$ & 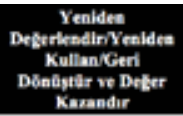 & $\begin{array}{l}\text { Kanhline } \\
\text { Tauarie I } \\
\text { Keadli Yap }\end{array}$ & 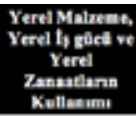 \\
\hline 2013 & 3 & 3 & 1 & 2 \\
\hline 2012 & 7 & 2 & - & - \\
\hline 2011 & 9 & 1 & 2 & - \\
\hline 2010 & 10 & 1 & - & 2 \\
\hline 2009 & 5 & 1 & - & - \\
\hline 2008 & - & - & - & - \\
\hline Toplam & 34 & 8 & 3 & 4 \\
\hline
\end{tabular}

Tablo 1 Vogue.com sitesinde yayınlanan etik moda haberlerinin yıllara göre dağılımı

\begin{tabular}{|c|c|c|c|c|}
\hline Elle & $\begin{array}{l}\text { Cevre Dostu } \\
\text { Mabzemelerin } \\
\text { Kullenumi }\end{array}$ & 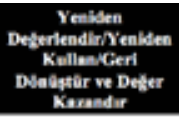 & $\begin{array}{l}\text { Katilima } \\
\text { Tasurim f } \\
\text { Keselin Yap }\end{array}$ & 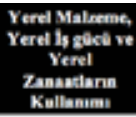 \\
\hline 2013 & 1 & 1 & - & - \\
\hline 2012 & 3 & - & - & 2 \\
\hline 2011 & 8 & 2 & - & - \\
\hline 2010 & 5 & 3 & - & 4 \\
\hline 2009 & 9 & 4 & - & - \\
\hline 2008 & 4 & - & - & - \\
\hline Toplam & 30 & 10 & - & 6 \\
\hline
\end{tabular}

Tablo 2 Elle.com sitesinde yayınlanan etik moda haberlerinin yıllara göre dağıımı

\begin{tabular}{|c|c|c|c|c|}
\hline Ecouterre & 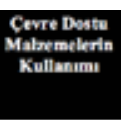 & 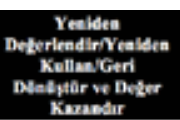 & $\begin{array}{c}\text { Kathima } \\
\text { Tasanmm } \\
\text { Kendin Yap }\end{array}$ & 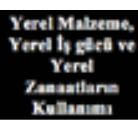 \\
\hline 2013 & 6 & 5 & 1 & 15 \\
\hline 2012 & 45 & 27 & 6 & 25 \\
\hline 2011 & 88 & 50 & 6 & 18 \\
\hline 2010 & 37 & 56 & 8 & 18 \\
\hline 2009 & 25 & 14 & 4 & 3 \\
\hline 2008 & 1 & - & - & - \\
\hline Toplam & 202 & 152 & 25 & 79 \\
\hline
\end{tabular}

Tablo 3 Ecouterre.com sitesinde yayınlanan etik moda haberlerinin yıllara göre dağılımı

Bu tablolar istatistiki veri olarak baz alınmamalıdır. Veriliş amaçları anahtar kelimelerle arama yapıldığında listelenen sonuçlar içerisinden araştırma kısıtlamaları kapsamında okur karşısına çıkan ortalama haber sayısını vermektir. Ayrıca haber oranlarını karşılaştırmak ve çalışmada belirtilen dört faklı tasarım yaklaşımına ne derecede yer verildiğini göstermek açısından değer taşımaktadır. Elbette, Ecouterre içeriğini etik moda ekseninde kurguladığından diğer sitelere oranla daha çok yazı barındırmaktadır. Ancak, moda endüstrisine yön veren en önemli iki derginin etik moda konusuna yaklaşımları ve haber yapma sıklıkları göz ününde bulundurulduğunda ortaya çıkan sonuç düşündürücüdür.

Üç sitenin ortak noktası en fazla haberi çevre-dostu malzemelerin kullanıldığı tasarımlar hakkında yapmalarıdır. Ana akım medyanın bu konuda yaptığı haberlerin yoğunluğu diğer değerlerle ilgili haber sayılarıyla kıyaslandığında etik ve sürdürülebilir moda söylemini çoğunlukla ekolojik malzemelerin kullanıldığı koleksiyonlara indirgediğini göstermektedir. Geri dönüştürme ve değer kazandırma kategorisi ise ikinci derecede yoğunluktadır. Ana akım medyanın bu konuya olan ilgisinde hâlihazırda yıllardır 
haberlerini yaptıkları Martin Margiela gibi bu değeri benimseyen yüksek moda markalarının rolü büyüktür. Bu alanda yapılan haberlerin büyük bölümünde Margiela'nın öncülük ettiği geri dönüşüm estetiğine vurgu yapılmıştır. Ecouterre ise bu uygulamalara geniş yer vermiş ve bu pratiğin oluşumunu destekleyen birçok farklı tasarımcıyı haberlerine taşımıştır. Ana akım dergilerin sitelerinin katılımcr tasarıma neredeyse hiç yer vermemesi dikkat çekicidir. Aynı şekilde yerellik vurgusu yapılan, eşit ve adaletli ticareti destekleyen haber ve makaleler Ecouterre'e kıyasla konvansiyonel medya tarafından çok rağbet görmemiş̧ir. Bu durum etik modanın söylemini oluşturan tasarım prensiplerinin konvansiyonel medya tarafından eşit olarak benimsenmediğini ve okura yansıtılmadığını göstermektedir.

\section{Geriye Bakış ile Dört Etik Markanın Dijital Ortamdaki Haberlerinin Değerlendirilmesi}

Çalışmanın ikinci aşamasında etik prensipleri yorumlama kriteri olarak bazı tasarımcılar vaka analizi olarak seçilmiş, bu tasarımcıların biyografik ve koleksiyon okumaları yapılmış ve söz konusu medyada yer alma biçimleri ve içerikleri incelenmiştir. Bu tasarımcılar seçilirken Vogue ve Elle'in yalnızca bir takım tasarımcı ve firmaların haberlerini yapmaları da göz önünde bulundurulmuştur. Ecouterre'de haberi yapılan pek çok farklı tasarımcı varken Elle ve Vogue genellikle kısıtlı sayıda firmayı gündeme taşımıştır. Makale ve haberlerin yazım biçimlerini karşılaştırabilmek için her üç sitede de haberi yapılan tasarımcıların seçimi kaçınılmazdır. Bu tasarımcılar aşağıda verilmiştir;

\section{1. Çevre Dostu Malzemelerin Kullanımı Için: Organic by John Patrick}

Organic by John Patrick, organik ve çevre dostu tasarımlar yapan bir firmadır. Organik pamuk, Vermont yünü ve kendi yetiştirdiği keten ve geri dönüştürülen doğal kumaşlardan oluşturduğu koleksiyonları 100\% organik giyim olarak değerlendirilmektedir. Organik giysi tasarımının yanı sıra, yerel işgücü ve zanaatların kullanımına yönelik şeffaf üretim sistemlerini de önemser.

\section{Yeniden Değerlendirme/Yeniden Kullanım/Geri Dönüştürme ve Değer Kazandırma Yaklaşımı ççin: Martin Margiela - Artisanal Line}

Margiela, Yapısökümcü Tasarım bölümünde yer verildiği gibi "Artisanal" çizgisi ile kullanılmış malzemelere, giysi ve eşyalara yüksek düzeyde elişçiliği ile yeni bir hayat vererek, değer olgusunun yenilik ile değil, emek ile oluşturulabileceğini savunur. Eskinin yaşatılması gerektiğine inanan tasarımcı el emeğinin bir şeyi olduğundan daha değerli kıldığına inanır.

\section{Kendin Yap ve Katılımcı Tasarım Için: Junky Styling}

Junky Styling katılımcı tasarımı uygulayan öncü bir tasarım ekibidir. Tüm koleksiyonları yüksek kalitede ikinci el giysilerden üretilmektedir. Yapısöküm yöntemi ile parçalara ayrılıp, yeniden biçimlendirilen eski giysiler yenilerine dönüştürülür. 'Gardırop Ameliyatı' adını verdikleri deneysel koleksiyonlarında ise tüketicinin giysi yapımına müdahale edebileceği katılımcı bir tasarım süreci gerçekleştirirler (Sanders 2009). Bu süreç, tüketicilerin eski giysilerin dönüşümünde onların istekleri doğrultusunda şekillenen, kişiselleştirilmiş yeni giysinin oluşumuna dayanır.

\section{Yerel Malzeme, Yerel İşgücü ve Yerel Zanaatların Kullanımı Için: Edun}

Edun, giysi üretiminin önemli bir bölümünü Afrika'da gerçekleştirir. Çevre dostu malzemeler kullanarak oluşturduğu tasarımların üretiminde Uganda ve Kenya bölgesinin yerel işgücünden yararlanarak Afrika ülkelerinin tekstil ticareti ve giyim üretiminde görünürlüğünü sağlar. Sosyal sorumluluk yaklaşımları yerel zanaata yönelik topluluklara iş imkanı sağlamakla sınırlı kalmaz; 2008 yılında Edun Wildlife Conservation Society ile birlikte Conservation Cotton Initiative Uganda'yı kurar ve Invisible Children oluşumu ile yerel çiftçileri finansal olarak destekler.

Belirtilen firmalara dair incelenen haber ve makaleler dört farklı yazım biçimi altında analiz edilmiştir:

1. Betimsel Yazım: Giysi ve koleksiyonlar üzerinde 
tasvire dayalı açıklamaların yapıldığı yazım biçimi

2. Diyalojik Yazım: Röportaj veya alıntıya dayalı, tasarımcıların görüşlerini yansız biçimde aktarmayı amaçlayan direkt bilgi akışı sağlayan yazım biçimi

3. Promosyonel Yazım: Açık veya üstü kapalı bir biçimde bahsi geçen firmanın reklamının yapıldığı promosyona yönelik yazım tarzı

4. Eleştirel ve Analitik Yazım: Spesifik konuların ve tasarım yaklaşımlarının değerlendirildiği yazım biçimi

Yukarıda tanımlanan yazım biçimlerinin etik moda söylemi açısından farklı işlevleri vardır. Örneğin; çevredostu malzemelerin kullanımını vurgulamak isteyen bir yazar çoğunlukla betimleyici yazım tarzını benimserken, hızlı modanın yıkıcı etkilerine karşı bilinç geliştirmeyi hedefleyen bir yazar, tasarımcının yaklaşım değerlendirmesini eleştirel ve analitik yazım tarzıyla yapabilmektedir. Bu noktada, Wilson'ın belirttiği gibi dergilerin reklam yaparak tüketimi özendirmek yerine eğitici bir dil benimsemeleriyle toplumun bakışını etik değerler çerçevesinde şekillendirebilecekleri hatırlanmalıdır. Bu sebeple, etik yayın anlayışını benimseyen basının okurlarına promosyonel yazım tarzından çok betimleyici, eleştirel/analitik ve tasarımcının fikirlerini yansızca aktaran diyalojik yazım tarzındaki yazılarla seslenmesi beklenir. Belirtilen düşünceler ışığında seçilen firmaların haber ve makalelerindeki farklılıklar aşağıdaki biçimde incelenmiştir:

'Organic by John Patrick: OJP' üzerine Vogue'da 17 , Elle'de dört, Ecouterre'de ise 30 haber yapılmıştır. Elle'de yayınlanan haberler promosyonel yazım tarzı kategorisine girmektedir. Haberlerin tümü oldukça kısadır. Yalnızca bir tanesinde çevre dostu ürünler ürettiğine değinilmiştir. Vogue'da yayınlanan makale ve haberlerin dördü betimleyici, yedisi promosyonel, beşi ise hem promosyonel hem betimleyicidir. Ilaveten bir haberde Patrick'in moda dışındaki sürdürülebilirlikle ilgili aktivitelerinden bahsedilmiştir. Betimleyici haberlerde koleksiyonlara dair trend bilgisinin, kullanılan ekolojik ürünlere dair bilgi vermenin önüne geçtiği gözlemlenmiştir. Organik ve çevre-dostuürün kullanımının çevre ya da insan üzerindeki olumlu etkilerine hemen hiç değinilmediği gibi ekomoda ve organik terimleri etiket olarak yer almış ancak içeriği aktarılmadan, değinilip geçilmiştir. 2011 sonbahar koleksiyonunun defilesi ile ilgili bir değerlendirmede Patrick'in üretim sürecini şeffaflaştırmaya yönelik bilgilendirici sunumuna izleyicilerin ilgisizliğinden bahsedilmiştir (Holt, 2011). Tasarımcının ekolojik bir bilinçle tasarım yapmasını haberde artı değer olarak aktaran Vogue, tasarımcının bilgilendirme yöntemine yer verirken, bu yorumla, tüketicinin ilgisizliğine dikkat çekmiş ancak, bu ilgisizliği normalleştirmiştir. Ecouterre'deki haberlerin 11'i promosyonel, 15'i betimleyici, biri hem betimleyici hem promosyonel, ikisi eleştirel/analitik ve biri diyalojik yazım tarzındadır. Diyalojik yazılar tasarımcıların görüşlerini yansız bir biçimde aktarma aracıdır. Ecouterre'deki bu yazıda hem John Patrick'in koleksiyonlarında kullanılan malzemelerin ve üretim biçimlerinin nitelikleri açıklanmış hem de etik moda hakkındaki yorumlarına yer verilmiştir. Böylece okuyucu yalnızca ürünler hakkında bilgilendirilmek yerine etik moda söylemini yaratan düşünce ve uygulamalara da hâkim kılınmıştır. Betimleyici haberlerde OJP'in kullan-at tarzı tüketim kültürüne karşı çıkışı yalnızca çevre dostu ve geri dönüştürülmüş malzemeler kullanmasıyla vurgulanmıştır. Bunlara ilaveten OJP'in hazırladığı ve tüketicinin kendisinin uygulayabileceği bir katılımcı tasarım örneği verilmiştir. Eleştirel ve analitik kategorisindeki makalelerde kaynak kullanımının etik bir biçimde yapılmasının önemine vurgu yapılırken OJP'nun benimsediği elektronik yöntemlerin tanıtımıyla tasarımcıları ve tüketicileri bilgilendirmek hedeflenmiştir. Konvansiyonel medyada reklam dilini benimser tarzda bir üslupla daha çok tasarımcının ürünlerine vurgu yapılırken, Ecouterre'de tüketiciyi bilgilendirme amacı taşıyan görüş ve uygulamaların temsili daha geniş yer bulmuştur.

Martin Margiela-Artisanal Line: Konvansiyonel medyada Margiela'nın ortaya koyduğu diğer koleksiyonlar hakkında pek çok haber ve fotoğraf bulunduğu halde Artisanal Line hakkında çok az sayıda haber bulunmakta- 
dır. Vogue'da koleksiyonların detaylarından bahsedilen 4 adet betimleyici, Elle'de iki adet betimleyici, Ecouterre'de ise biri promosyonel, üçü betimleyici olmak üzere toplam dört adet haber yer almıştır. Vogue'daki haberler incelendiğinde iki tanesinde Artisanal Line ile tasarımla değer kazandırma (upcycling) kavramının konvansiyonel medyanın sözlüğüne de girdiği görülmüştür, fakat haberlerden birinde bu kavramın çevreci hareketlerle özdeşleştirilmemesi gerektiği vurgulanmış, diğerinde ise sadece bir tasarım yöntemi olarak sunulmuştur (Holgate, 2013; Mower, 2010). Yani geleneksel tüketim yöntemlerine karşı çevreci bir söylem yaratma ve modanın değer yaratma kavramına eleştirel bir direnç oluşturma amacı taşıyan bu uygulama şekli tamamıyla dışlanmıştır. Diğer iki haberde ise bu kavrama değinilmemiştir. Elle, Ecouterre'e kıyasla daha çok giysilerle ilgili teknik detaylardan bahsetmiş, değer kazandırma ilke ve söylemini içeren bir ifade kullanmamıştır. Margiela'nın benimsediği etik duruş ve yaklaşım en iyi şekliyle Ecouterre'de paylaşılan “CHICAGO EXHIBIT: ZERO Waste: Fashion Re-Patterned" haberinde ifade edilmiştir (Chua, 2011). Bu haberde Margiela'nın da aralarında bulunduğu bir grup aktivist tasarımcının yaptığı bir sergi tanıtımı üzerinden modanın tüketim kültürüyle olan bağlantısı vurgulanmış, sistemin yarattığı atıkların yaratıcı bir biçimde geri-dönüştürülmesinin örneklenmesinde yine bu tasarımcıların yöntemleri ve eserlerinin sunulacağından bahsedilmiştir.

Junky Styling: Konvansiyonel dergilerin hiçbiri Junky Styling hakkında haber yapmamıştır. Bunun başlıca sebeplerinden birinin IS'in ana akım medyaya reklam vermemesi olduğu gözlenmektedir. Ecouterre'in yayınladığı dokuz makaleden üçü betimleyici, dördü promosyonel ve ikisi eleştirel/analitiktir. Makalelerin büyük bir bölümünün amacı IS ürünlerinin tanıtımını yapmak yerine tüketim kültürüne olan eleştirel bakışlarını ve katılımcı tasarım yöntemi ile sağlamak istedikleri demokratik tasarım pratiğine dikkat çekmektir. Haberlerin üçünde hızlı moda sisteminin eleştirisi yapılırken IS'in etik uygulamaları örnek olarak verilmiştir. Böylece Ecouterre'in birincil amacının marka promosyonu yapmak yerine etik moda söylemi- ni yaratan uygulama ve düşünceleri desteklemek olduğu vurgulanmıştır.

Edun: Edun hakkında Vogue'da üç, Elle'de sekiz ve Ecouterre'de 28 adet haber bulunmaktadır. Vogue'daki haberlerin üçü de promosyonelken, Elle'de altı adet promosyonel ve iki adet betimleyici haber bulunmaktadır. Betimleyici haberlerden biri herhangi bir yazı içermemekte, yalnızca fotoğraflarla Edun'un Afrika'da yapılan üretimi anlatılmaktadır. Diğer betimleyici haber ise adil ticarete, sosyal sorumluluk bilincine dikkat çekmesi nedeniyle aynı zamanda eleştirel ve analitik kategorisine de girebilmektedir. Bu ana akım medyada yayınlanan tek farklı yazım biçimini oluşturmuştur. Ecouterre'deki haberlerin 20'si reklam amacı taşırken sekizi betimleyicidir. Ecouterre'deki haberlerde yalnızca Edun ürünlerine yer verilmemiş, aynı zamanda Edun'un katıldığı etik ve adil ticaret konularında bilinç oluşturmaya yönelik etkinliklerden bahsedilmiştir. Konvansiyonel medya ve Ecouterre arasındaki en büyük içerik farklılığı Vogue ve Elle'in genellikle giysilerle ilgili trend ve teknik detaylara yönelik bilgi vermesine karşın Ecouterre'in yerellik kavramına vurgu yapması olmuştur. Ecouterre'de Edun'un yerel zanaat kültürü ve işgücünden yararlanmasının altı çizilirken, üretimin yalnızca bir bölümünü Afrika'da yapması eleştirilmiştir. Ayrıca firmada yaşanan ekonomik sıkıntılar da çekinmeden dile getirilirken Vogue ve Elle tamamıyla pozitif bir resim çizmiş ve okuyucunun doğru bilgive ulaşımını kısıtlamıştır. Ecouterre promosyonel olarak yorumlanan haber ve makalelerde bile etik moda söylemini oluşturan tasarım pratiklerine etik moda çerçevesinden bakarken, konvansiyonel medya daha çok markanın promosyonuna hizmet etmiştir.

\section{Sonuç}

Etik moda hareketi, çevresel kirliliğe, tüketime yönelik üretim anlayışına, iş gücü sömürüsüne, adil olmayan ticarete karşı geliştirilen uygulamaların tümünü kapsar. Dolayısıyla sadece baskın çevresel, sosyal ve ekonomik politikalara değil, moda sisteminin kendisine karşı geliştirilen aktivist bir harekettir. Bu başkaldırı tabandan yayı- 
lan bir dönüşümdür. Elbette diğer tüm eleştirel yaklaşımlar, avangard hareketler gibi etik moda da sistemin pazar ekonomisi tarafından asimile edilme tehdidi altındadır. Ancak yine de kendi söylemini, moda sistemini dışlayarak geliştirmek yerine sistemin içinde başat moda söyleminin dekonstrüksiyonunu yaparak geliştirir. Etik modanın söylemi tasarım-üretim-tüketim döngüsüne yönelik olduğu kadar modanın iletişimi ve temsiliyetine de yöneliktir. Moda söyleminin ve moda medya söyleminin birbirlerini sürekli olarak karşılıkı ürettikleri göz önüne alındığında, etik moda söyleminin bağımsız bir medya söylemi üzerinden var olabileceği anlaşılır.

Etik modanın tasarım, üretim ve tüketim ilkeleri çaıışma boyunca dört ana başlıkta tanımlanmaktadır. Bu değerler bağlamında, etik modanın temsiliyeti ana akım medyada ve etik moda medyasında karşılaştırmalı olarak incelendiğinde, etik modanın gerçek değerinin ana akım medyada verilmediği kolaylıkla söylenebilir. Medya söyleminin içerik ve biçim bütünlüğünden oluştuğu düşünülürse bu analizi yapmak için içeriği ifade eden değerler kadar, değerlerin hangi yazım biçimleri ile temsil edildiği de önem kazanır. Her biri bir etik moda değerini temsil eden dört tasarımcı üzerinden, dört farklı yazım biçimi temel alınarak Vogue, Elle ve Ecouterre'de çıkan haberler incelenmiştir. Etik modanın sunum, iletişim ve satış kanallarının demokratik ve interaktif bir iletişim ortamı sunan internet üzerinden gelişimine istinaden bu üç derginin 2008-2013 yılları arasındaki geriye dönük okumaları etik moda değerlerinden üretilen anahtar kelimelerle yapılmıştır. İstatistik bir veri oluşturma amacı taşımadan yapılan bu okumalar, etik modanın medyadaki temsiliyetinin bir paradigmasını oluşturur niteliktedir. Bu araştırma etik modanın temsiliyetinin inandırıcı olması için bilgilendirici-betimsel ve aynı oranda eleştirel/analitik bir yazım biçiminin benimsendiğini göstermiştir. Ayrıca diyalojik yazıların her iki medyada da popüler olmasına karşın ana akım medyanın yer verdiği tasarımcıların etik moda tasarımcıları olmadığı gözlenmektedir.

Konvansiyonel medyanın içerik ve biçim inşasında, hem derginin gelir kaynağını garantileyen, hem de tüke- time özendiren reklam içerikli promosyonel yazım biçimlerine sıklıkla rastlanmaktadır. Ana akım medya bu biçimi yalnızca trend odaklı lüks ve hızlı moda markaları açısından yapmamakta, aynı zamanda etik moda markalarına yer verirken de bu markaların değerler sistemini görmezden gelerek, onları metalaştırmakta ve 'yeşil bir biçimde tüket' anlayışı ile alternatif bir tüketim kanalını inşa etmektedir. Bu yaklaşım, modanın doğrusal hiyerarşisinde okuyucuyu pasif tüketici olarak konumlandıran ve Baudrillard'ın 'yanıtsız iletişim' olarak tanımladığı iletişimsiz bir ortam yaratmaktadır. Buna karşın, etik moda medyası kullanıcı/okuyucuyu sisteme müdahil olan ve içeriğine katkıda bulunan bir rolde kurgulayarak, eğrisel ve adhokratik bir iletişimin kurulmasını sağlar. Buradan hareketle ana akım moda basınının etik modaya bakış açısının kendine dönük ve kapalı "yüceltilmiş bir söylemi” benimsemekten ileri gidemediği, buna mukabil etik moda medyasının kendi içinde eleştirel, 'gerçek bir söylemi' benimsediği sonucuna varabiliriz. İlaveten, medya Kawamura'nun tespit ettiği gibi "susma ve yer verme" hakkını kendi söylemi doğrultusunda kullanır; bu bağlamda ana akım medya etik modayı ya etik bağlamından kopartarak temsil ettiği markalar doğrultusunda değişim değeri olarak sunar, ya da moda dergileri okuyucuları tüketici olarak kabul ettiklerinden örneğin Junky Styling gibi, reklam vermeyen tasarımcılar konusunda sessiz kalmayı tercih eder.

\section{Kaynakça}

Arnold, R. (2009). 'Ethics' in Fashion: A very Short Introduction. Oxford: Oxford University Press.

Baudrillard, J. (1972). "Requiem for the Media", The New Media Reader, s.277-288.

Baudrillard, J. (1981). For a Critique of the Political Economy of the Sign Paperback, Telos Press Publishing.

Black, S. (2008). Eco-Chic the Fashion Paradox. London: Black Dog Publishing.

Braungart, M. and McDonough, W. (2009).Cradle to Cradle: Remaking the Way We Make Things,. London: Vintage.

Breward, C. (1995).The Culture of Fashion Manchester: Manchester University Press. 
Brown. S. (2010). Ecofashion. London: Laurence King Publishing Ltd.

Chapman, J. and Gant, N. (2007).Designers, Visionaries and Other Stories: A Collection of Sustainable Design Essays. Sterling: Earthscan.

Clark, Hazel. (2008). "Slow+Fashion- an Oxymoron- or a Promise for the Future...?”, Fashion Theory, cilt. 12, sayı.4, s. 427-446.

Craik, J. (1993). The Face of Fashion.London; New York: Routledge.

Craik, J. (2009). Fashion: The Key Concepts. Oxford: Berg Publishers.

Currie, D.H. (1994). "Going Green" Mythologies of Consumption in Adolescent Magazines, Youth Society. Erişim Yeri: Sage database [Şubat 15, 2012]

Derycke, L. \& Van de Veire, S. (1999).Belgian Fashion Design, Ludion, Antwerp, p. 292, P Mears, 'Fraying the Edges: Fashion and Deconstruction'içinde, Mears, P. \& Sidlauskas S. (ed), (2006), Skin+Bones: Parallel Practices in Fashion and Architecture içinde, Thames and Hudson Pub., London, s. 35.-

Dilnot, C., (2009). “Ethics in Design: 10 Questions”, Design Studies: A Reader, ed. Clark, H., Brody, s. 180-190.

Erlhoff, M. and Marshall, T. (ed) (2008).Design Dictionary: Perspectives on Design Terminology. Basel: Birkhäuser Verlag

Evans, C.,(1998). The Golden Dustman: A Critical Evaluation of the Work of Martin Margiela: Exhibition,Fashion Theory, vol. 2 Issue 1: 83, Berg publishers.

Fletcher, K. (2008). Sustainable Fashion and Textiles: Design Journeys. Malta: Earthscan.

Healy, R. (2007). The Parody of Motley Cadaver: Displaying the Funeral of Fashion' in EAD 07 Conference Proceedings: Dancing with Disorder. Design Discourse Disaster.Balcıoğlu T., Tombuş Ö.Ç., Irkdaş, D(Ed)s.660-667.Izmir University of Economics

Herman, A. and Swiss, T. eds. (2000). The World Wide Web and Contemporary Cultural Theory. Newyork: Routledge.

Kawamura, Y. (2005). Fashion-ology: An Introduction to Fashion Studies. Oxford: Berg Publishers.

Kipöz, Ş (2013) 'Slow Fashion Ethics: Reproduction of Memory through Deconstruction', EAD 2013 Conference Proceedings: Crafting the Future, Erişim Yeri: http://www.trippus.se/web/ presentation/web.aspx ?evid $=q T C R a T 4 T$ T0WGtClyjpKRA $==$ \&ecid= vajn7H5hFUL31Hr+Q9enuw $==\& \ln =$ eng \&emid $=3 \mathrm{I} G \mathrm{so}$ ZYZLLIcleu9tHBhtg==\&view=infopage\&template $=$ desktop

Kipöz, Ş., Güner, D. (2011). Conceptual Resistance of Hussein Chalayan within the Ephemeral World of Fashion in Fashions: Exploring Fashion through Culture, Foltyn, J. L. (Editor).0xford: The Inter-Disciplinary Press.
Loschek, I. (2009).When Clothes become Fashion: Design and Innovation Systems. London: Berg Publishers.

Manzini, E. (1995). Prometheus of the Everyday in Discovering Design: Explorations in Design studies. Margolin, V., Buchanan, R. (eds) s.219-243. Chicago: The University of Chicago Press.

Margolin, V. (2002). "Design for a Sustainable World”, Politics of the Artificial, s.92-105. Chicago: The University of Chicago Press.

Mears, P. and Sidlauskas, S., (ed). (2006). 'Fraying the Edges: Fashion and Deconstruction', in Skin+Bones: Parallel Practices in Fashion and Architecture, London: Thames and Hudson Pub.

O'shaughnessy, M. and Stadler, J. (2008).Media and Society. Sydney: Oxford University Press.

Rocamora, A. (2009).Fashioning the City: Paris, Fashion and the Media. London\& New York: I.B.Tauris \& Co Ltd.

Sanders, A. And Seager, K. (2009).Junky Styling Wardrobe Surgery. London: A\&C Publishers.

Scaturro, S. (2008). Eco-tech Fashion: Rationalizing Technology in Sustainable Fashion. Fashion Theory, vol. 12, issue.4, s. 469489

Shinkle, E., ed. (2008).Fashion as Photograph: Viewing and Reviewing Images of Fashion.London: I.B. Tauris \& Co Ltd.

Thomas, S. (2008). From Green Blur to Ecofashion: Fashioning an Eco-lexicon,Fashion Theory, vol. 12, issue.4, s. 525-540.

Thorpe, A. (2010). Design's Role in Sustainable Consumption, Design Issues, vol.26.no.2, Chicago: Mit Press.

Welters, L. and Lillethun, A., eds. (2007). The Fashion Reader. 0xford: Berg Publishers.

Winge, Theresa M. (2008). "Green is the New Black: Celebrity Chic and the "Green" Commodity Fetish", Fashion Theory (12/4): 511-524.

Whiteley, N., (1994). "Responsible Design and Ethical Consuming”, Design for Society, s.94-133.

Wolbers, M. F. (2009). Uncovering Fashion: Fashion Communications Across the Media. New York: Fairchild Books.

Zimmer, M.R., Stafford, T.F. and Stafford, M.R., (1994). "Green issues: Dimensions of Environmental Concern". Journal of Business Research (30): 63-74. 


\section{Internet Kaynakları}

Chua, J. M. (2011).Chicago Exhibit: Zero Waste: Fashion RePatterend[çevrimiçi].Erişim yeri:http://www.ecouterre. com/chicago-exhibit-zer\%C3\%98-waste-fashion-repatterned/[Erişim tarihi: 15 Mart 2012].

Grandpierre, Karine. (2013). How ELLE magazine conquered the world[çevrimiçi].Erişim yeri: http://www.inaglobal.fr/en/ press/article/how-elle-magazine-conquered-world.[Erişim tarihi: 20 Temmuz 2013].

Holt, E. (2011).Organic by John Patrick /Fall 2011 Review [çevrimiçi].Erişim yeri:http://www.vogue.com/fashionweek/fall-2011/organic-by-john-patrick/review/.[Erişim tarihi: 20 Temmuz 2013].

Holgate, M. (2013).Maison Martin Margiela/Spring 2013 Couture[çevrimiçi].Erişim yeri:http://www.vogue.com/ fashion-week/spring-2013-couture/maison-martinmargiela/review/.[Erişim tarihi: 10 Temmuz 2013].

Mower, S. (2010).Couture 2010: Martin Margiela's Artisanal Line[çevrimiçi].Erişim yeri:http://www.vogue.com/voguedaily/article/vd-couture-2010-martin-margielas-artisanalline/\#1[Erişim tarihi: 17 Mart 2012]. 